\title{
AMINO ACID COMPOSITION AND ANTI-TYROSINASE ACTIVITY OF METABOLITES FROM EDIBLE Pleurotus SPECIES FOR THEIR NUTRITIONAL AND THERAPEUTIC POTENTIAL
}

\author{
Iyabo O. Omomowo ${ }^{1}$, Comfort O. Bamigboye ${ }^{1}$, Olawale I. Omomowo ${ }^{2}$, Olusola N. Majolagbe ${ }^{1,3}$, \\ Adijat F. Ogundola ${ }^{1}$, Julius K. Oloke ${ }^{1}$
}

${ }^{1}$ Department of Pure and Applied Biology, LadokeAkintola University of Technology, P.M.B. 4000, Ogbomoso, Oyo State, Nigeria
${ }^{2}$ Department of Microbiology, University of Maiduguri, P.M.B. 1069 Maiduguri, Maiduguri, Borno State, Nigeria
${ }^{3}$ Microbiology Programme, College of Agriculture, Engineering and Sciences, Bowen University Iwo, Osun State, Nigeria

Received - August 05, 2021; Revision - November 02, 2021; Accepted - December 20, 2021

Available Online - December 30, 2021

DOI: http://dx.doi.org/10.18006/2021.9(6).837.850

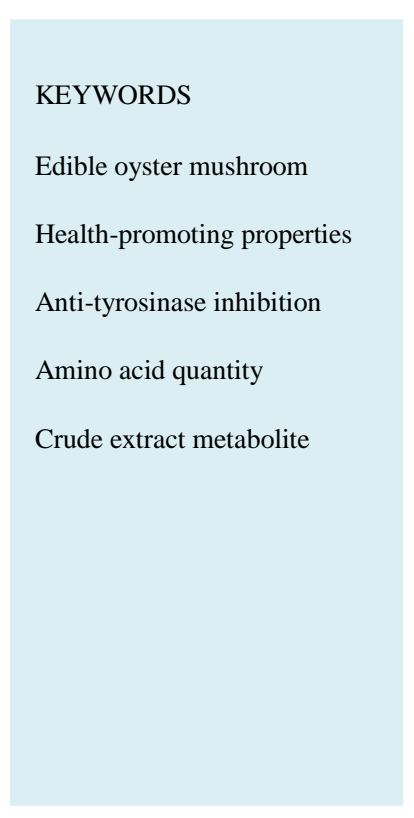

\begin{abstract}
Mushrooms are being extensively researched due to their nutritional value and medicinal importance. The genus Pleurotus is the second most cultivated mushroom and is known for its high nutritional value, therapeutic properties, taste, flavor, as well as their application in biotechnology and environmental study. Also, tyrosinase is prevalent in most living organisms. The enzyme catalyzes the oxidation of monophenols to ortho-quinones in a two-step reaction process. This study was aimed to assess the amino acid composition and anti-tyrosinase activity of metabolites obtained from edible Pleurotus species. Assessment of the nutritional content and inhibitory studies of mushroom tyrosinase produced from four Pleurotus strains was carried out using high-performance liquid chromatography (RP-HPLC). The results of the study showed that seventeen different amino acids were identified in the crude and partially purified protein metabolites. Also, the crude extract metabolite had the highest quantity of amino acids than the partially purified. The highest and lowest amino acids value Glutamic acid $(1343.26 \mu \mathrm{mol} / \mathrm{mL})$ and valine $(0.34$ $\mu \mathrm{mol} / \mathrm{mL}$ ). The anti-tyrosinase inhibition studies of the four Pleurotus strains showed varying results from significantly inhibitory effects to slightly inhibitory effects on mushroom tyrosinase. The highest inhibition was $14.86 \%$ (Pleu-W), while the lowest inhibition was $51.42 \%$ (Plof-30) respectively. The high point of this study is that the Pleurotus species contains a significant number of amino acids and also, they possess good anti-tyrosinase activity. Therefore, these are a good source of nutritional and therapeutic metabolites and these can be explored further for their nutritional and medicinal importance to man.
\end{abstract}

* Corresponding author

E-mail: afogundola@lautech.edu.ng (Ogundola Adijat Funke)

Peer review under responsibility of Journal of Experimental Biology and Agricultural Sciences.

Production and Hosting by Horizon Publisher India [HPI] (http://www.horizonpublisherindia.in/).

All rights reserved.
All the articles published by Journal of Experimental Biology and Agricultural Sciences are licensed under a Creative Commons Attribution-NonCommercial 4.0 International License Based on a work at www.jebas.org.

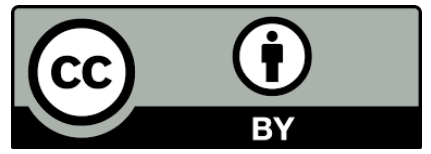




\section{Introduction}

A lot of people in the world live on grains, tubers, meat, and small quantities of pulses and vegetables; consequently, some human health problems have been attributed to the food consumption lifestyle. The increase in obesity and cardiovascular diseases among the growing human population due to the food consumption pattern is becoming an issue of great concern.

Mushroom has been appreciated for centuries as an important food and medicinal source. These are known as higher fungi or macrofungi; having both reproductive and vegetative phases (reproductive fruiting bodies and vegetative mycelia). Mushroom is lately considered as a goldmine of bio-actives nutrient and a key functional food with immense therapeutic potentials (Deepalakshmi \& Mirunalini, 2014; Ozturk et al., 2015; Sekan et al., 2019; Ianni et al., 2021).

Oyster mushrooms are well known as a very high nutritional/biological food that has an enhanced content of dietary fiber, amino acids, protein, vitamins, and unsaturated fatty acids (Michael et al., 2011; Kalac, 2013; Bach et al., 2017; CarrascoGonzález et al., 2017). The rapid increase/expansion of both cultivation/consumption of oyster mushrooms (Pleurotus species) is due to their excellent taste, enhanced value in terms of nutrition and therapeutic properties. They are a vital source of nutritional calories (proteins, dietary fiber, carbohydrates, among others). More so, they are cheaper to produce and possess medicinal properties such as anti-tumorigenic, antioxidant, antimicrobial properties, modulation of cholesterol (Corrêa et al., 2016; Dicks \& Ellinger, 2020). Importantly, the quick rate of growth of oyster mushrooms makes it an excellent resource for prospecting bioactive metabolites unlike plants for biotechnological applications (Chandra et al. 2020).

Tyrosinase (EC 1.14.18.1) is an enzyme of great significance in melanogenesis. This vital multi-copper enzyme sequentially catalyzes oxidation steps with various phenolic substrates. The first reactive step involves aromatic ring substitution with a hydroxyl group; this is known as "monooxygenase" or "cresolase" activity. While the second reaction step involves oxidizing the $o$-dihydroxy compound produced in the first reaction to an $o$-dopaquinone, this is "diphenolase" or "catecholase" activity. Molecular oxygen is essential for both reactions (Haghbeen \& Tan, 2003). These activities can be used as the basis for several biotechnological applications (Halaouili et al., 2006). Although tyrosinase is prevalent in most living things, but the emphasis is more on mushroom tyrosinase biotechnological potentials.

Tyrosinase is responsible for hyper-pigmentation / browning of vegetables and fruits, as well as melanogenesis in mammals (Dembitsky \& Kilimnik, 2016). Due to the key role of tyrosinase in the melanin pathway and its impact; the scientific community is focusing on characterizing newer anti-tyrosinase agents/inhibitors for different applications in agri-food industries, medicinal and cosmetic industries (Halaouli et al., 2005; Te-Cheng, 2009; Sahu et al., 2014). Moreover, with increasing biotechnological demands and applications of tyrosinase inhibitors, there is a need for improving the screening and development methods for these key enzyme inhibitory agents (Halaouili et al., 2006). An easier, ecofriendly, and sustainable means of production of anti-tyrosinase agents, as well as a rapid, sensitive, and accurate assay method, is highly necessary.

Therefore, this study was conceptualized because there is an everincreasing demand for functional/nutritional food with immense potentials as a goldmine of bioactive therapeutic metabolites. Also, there is a demand for new tyrosinase inhibitors to be applied in the food, cosmetics, and medicinal industries, using simple, rapid, and sensitive assay procedures.

\section{Materials and Methods}

\subsection{Mushrooms and liquid culture fermentation conditions}

The oyster mushrooms utilized in this investigation were provided/obtained from a mushroom germplasm culture collection, Plant Science Division, CSIR-NEIST, Jorhat, Assam-state, India. The strains designated as Pleu-W, Pleu-90, Plof-W, and Plof-30 were refrigerated at $4^{\circ} \mathrm{C}$ on (PDA) and re-culture bimonthly. All inoculations were carried out inside a laminar flow to ensure aseptic inoculation conditions. Wheat waste formulated liquid medium which was used in this study consist of Glucose $(50 \mathrm{~g} / \mathrm{liter})$, Peptone water (2.5g/liter), $\mathrm{KH}_{2} \mathrm{PO} 4$ (2g/liter), $\mathrm{MgSO}_{4} .7 \mathrm{H}_{2} \mathrm{O} \quad$ (1g/liter), $\mathrm{CaCl}_{2} .2 \mathrm{H}_{2} \mathrm{O}$ (1g/liter), Yeast extract (2.5g/liter), and $\mathrm{pH}$ 5.8. The fermentation medium was sterilized in an autoclave at $121^{\circ} \mathrm{C}$ for 15 minutes and $200 \mathrm{ml}$ was aseptically distributed into $250 \mathrm{ml}$ conical flasks. Inoculation into flasks was done by using three agar plugs of (6mm diameter) an actively growing Pleurotus strain. Inoculated flasks were incubated for 7 days using a shaker incubator at $150 \mathrm{rpm}$ at a temperature of $28^{\circ} \mathrm{C}$.

\subsection{Extraction of intracellular protein}

The mycelia mat was homogenized in a blender with $0.1 \mathrm{M}$ sodium phosphate buffer ( $\mathrm{pH}$ 7.0). This was now centrifuged at 10,000 $\mathrm{rpm}$ at $4^{\circ} \mathrm{C}$ for 10 minutes; the supernatant after centrifugation was used in the extraction of the crude protein by ammonium sulfate precipitation.

\subsection{Assay for tyrosinase inhibitory activities of Pleurotus strains}

Tyrosinase inhibitory assay was done by using Arung et al. (2006) protocol. Briefly, the inhibitory assay protocol consists of using 59 
$\mu 1$ of $0.1 \mathrm{M}$ phosphate buffer (pH 6.5), $47 \mu 1$ of L-DOPA (2.5 mM), and $70 \mu \mathrm{l}$ of each Pleurotus metabolite sample, this was followed by the addition of $24 \mu \mathrm{l}$ tyrosinase. Five minutes of incubation at $25{ }^{\circ} \mathrm{C}$ was done and the reading was reported at $475 \mathrm{~nm}$. The activity was monitored using UV/VIS, Sigma Spectrophotometer.

$$
\text { The inhibition rate }=100-\{A-B \div C-D\} \times 100
$$

A represent value for the complete reaction, $\mathrm{B}$ and $\mathrm{C}$ are the obtained values without tyrosinase and the Pleurotus metabolite solution, D represents value without Pleurotus metabolite and tyrosinase.

2.4 Determination and quantification of individual amino acids in crude and purified protein by (HPLC)

Individual amino acids in the Pleurotus strains, both crude and partially purified protein samples were quantified by a kit method using RP-HPLC column (HPLC, Waters, U.S.A.).

2.5 Sample preparation and HPLC amino acids analysis experimental procedure

The crude and partially purified protein metabolites of the Pleurotus strains were freeze-dried at $-20^{\circ} \mathrm{C}$ for 4 hours to powdery form. The lyophilized samples were transferred into vial bottles and kept in the freezers. From this, 0.05 grams of each sample were weighed and put separately in open-mouthed test tubes and $5 \mathrm{ml}$ of $6 \mathrm{~N} \mathrm{HCl}$ containing $1 \%$ phenol was added. The mouth of all the test tubes was sealed and digested for 24 hours at $100^{\circ} \mathrm{C}$ in a boiling water bath. After digestion, each sample was filtered using a $0.45 \mu \mathrm{m}$ pore size membrane filter (Tarsons). Then $1.5 \mathrm{ml}$ of the filtrate was taken and to it, $300 \mu 1$ of Ethanol: Water: Triethylamine (2:2:1) was added. All samples vortexed and then boiled in a water bath for 2 hours. This was followed by the addition of $60 \mu \mathrm{l}$ of derivatizing solution (Ethanol: Water: Triethylamine: Phenylisothiocyanate $($ PITC) $=(7: 1: 1: 1)$. This reaction mixture was mixed by vortexing and boiled at the hot water bath to remove traces of PITC. The samples were filtered using membrane filters $(0.45 \mu \mathrm{m})$. The filtrates were centrifuged at $6000 \mathrm{rpm}$ for 5 minutes to precipitate any impurities if present and the supernatant were collected.

The eluent was used for the analysis of free amino acid by a C18 column HPLC (Waters, 2489 UV visible detector). The flow rate of solvent is $0.8 \mathrm{ml} / \mathrm{min}$; Wavelength $280 \mathrm{~nm}$; Chart speed $1 \mathrm{~cm} / \mathrm{min}$; Injected sample of $20 \mu \mathrm{l}$; pressure is of $1,986 \mathrm{psi}$. From the prepared sample solutions, $20 \mu \mathrm{l}$ of each sample was directly injected into a reverse phase of the C-18 column. Each sample was run for 20 minutes, eluted with gradient elution of water and $35 \%$ of Acetonitrile containing $0.1 \%$ TFA, and the graph was recorded.

\subsection{Preparation of standard (amino acids)}

$5 \mu 1$ of each amino acid standard solution was taken and re-dried, derivatized, and then diluted with $200 \mu 1$ of sample diluent solution. The average of the triplicate sample was calculated, then compared with standard amino acids peak area and retention time on the column for estimation of amino acid present within the sample.

\subsection{Tyrosinase inhibition studies}

\subsubsection{Effects of DL-aspartic acid on tyrosinase inhibition}

The inhibitory effect of DL-aspartic acid on the activity of tyrosinase from Pleurotus strains (Pleu-W, Pleu-90, Plof-W, and Plof-30) were investigated using L-DOPA as substrate. The inhibitory effects of using different concentrations of $(2 \mathrm{mg} / \mathrm{ml}$ $10 \mathrm{mg} / \mathrm{ml}$ ) of DL-aspartic acid were used following standard assay procedure.

\subsubsection{Effects of Ascorbic acid and EDTA on Tyrosinase inhibition}

The inhibitory effects of EDTA and ascorbic acid were investigated on tyrosinases from the four Pleurotus strains (PleuW, Pleu-90, Plof-W, and Plof-30) using Kubo et al. (2003) protocol. Their concentrations were varied from $(2 \mathrm{mg} / \mathrm{ml}$ $10 \mathrm{mg} / \mathrm{ml}$ ) using standard assay procedure.

\subsubsection{Effects of Gallic acid}

Gallic acid (3, 4, 5-trihydroxybenzoate) were tested for their inhibitory effect on the tyrosinases from the four Pleurotus strains (Pleu-W, Pleu-90, Plof-W, and Plof-30). Varying concentrations $(2 \mathrm{mg} / \mathrm{ml}-10 \mathrm{mg} / \mathrm{ml})$ of gallic acid were used following the standard assay procedure.

\subsection{Statistical data evaluation}

The data evaluation was carried out by summing the means of three replicate and a one-way (ANOVA) of data was done. Differences at $p<0.05$ were considered to be significant. Origin Lab 8 statistical software was deployed.

\section{Results}

\subsection{Determination of amino acids composition}

Amino acid quantification was done to evaluate the nutritional composition of the protein metabolites in the crude and partially purified mushroom metabolite from the four Pleurotus strains. Different amino acid standards were used for comparisons. The chromatograms obtained with an RP-HPLC column are shown in Figures $1-9$. The names, peaks, and quantity of each free amino acid are also reflected in Tables $1-8$. Free amino acids detected in 
the metabolites are Aspartic acid, Glutamic acid, Asparagine, Serine, Glycine, Histidine, Glutamine, Threonine, Alanine, Proline, Tyrosine, Valine, Methionine, Cystine, Isoleucine, Hydroxy-proline, and Leucine. Generally, the crude protein metabolite had a higher quantity of amino acids than the partially purified one. Also, the amino acid quantities in the strains Pleu-90 and Plof-30 are higher than the quantities estimated in Pleu-W and
Plof-W. With regards to results of the partially purified protein metabolite of Pleurotus strains, (Pleu-W) had the highest amino acid value in Glutamic acid $1343.26 \mu \mathrm{mol} / \mathrm{mL}$, while the lowest amino acid value was reported for the valine $0.34 \mu \mathrm{mol} / \mathrm{mL}$. Also, the results of crude protein metabolite of Pleurotus strains indicated that (Plof-30) alanine concentration was highest 803.34 $\mu \mathrm{mol} / \mathrm{mL}$ while valine was lowest having $0.34 \mu \mathrm{mol} / \mathrm{mL}$.

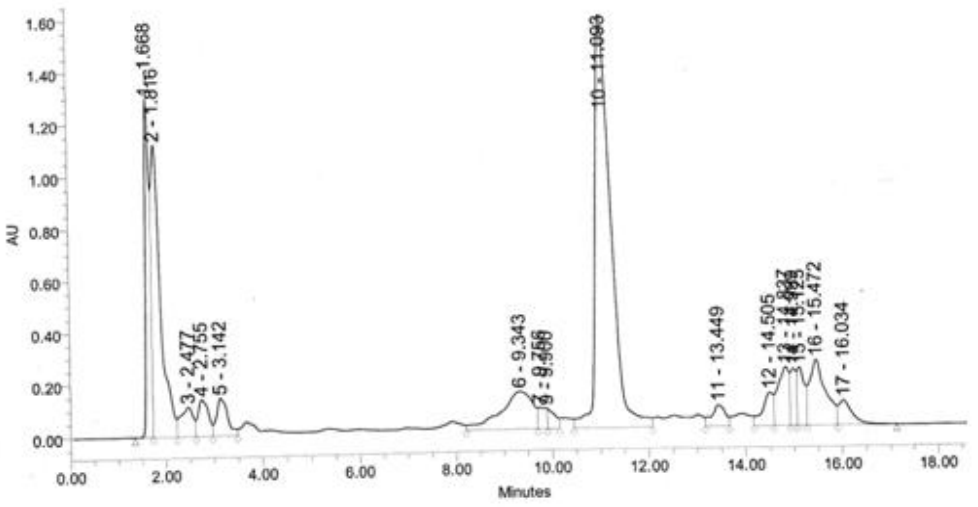

Figure 1 Chromatogram of amino acid composition present in crude protein metabolite of Pleurotus strain (Plof-30) analyzed by HPLC.

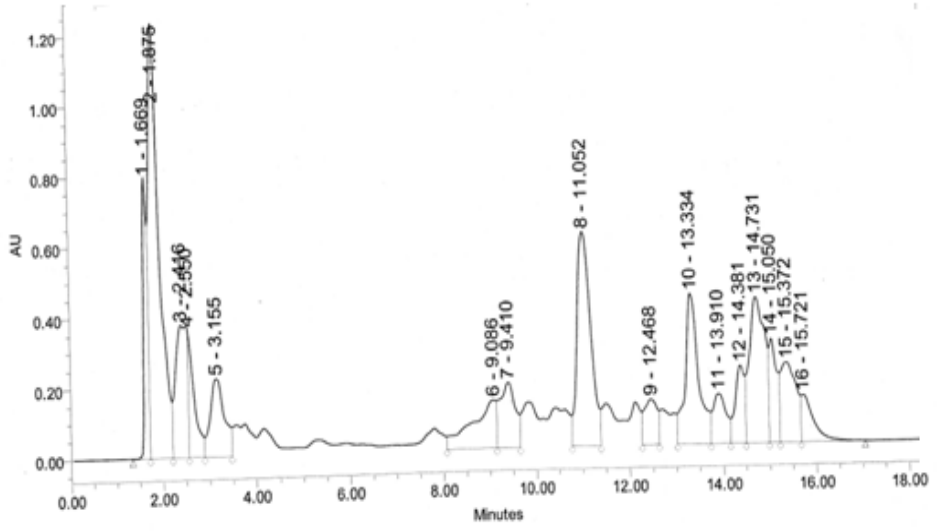

Figure 2 Chromatogram of amino acid composition present in crude protein metabolite of Pleurotus strain (Plof-W) analyzed by HPLC.

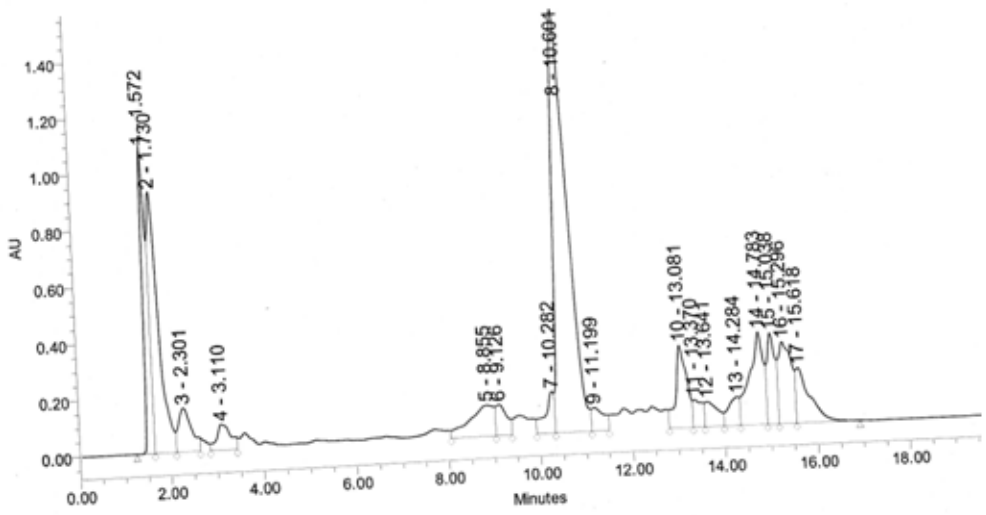

Figure 3 Chromatogram of amino acid composition present in crude protein metabolite of Pleurotus strain (Pleu-90) analyzed by HPLC.

Journal of Experimental Biology and Agricultural Sciences http://www.jebas.org 


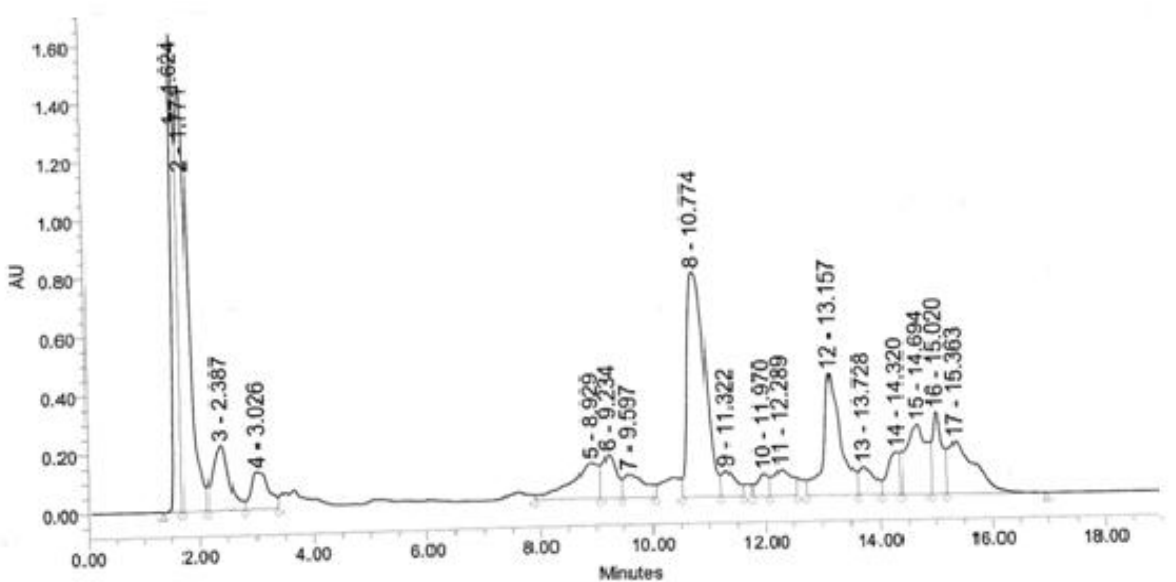

Figure 4 Chromatogram of amino acid composition present in crude protein metabolite of Pleurotus strain (Pleu-W) analyzed by HPLC.

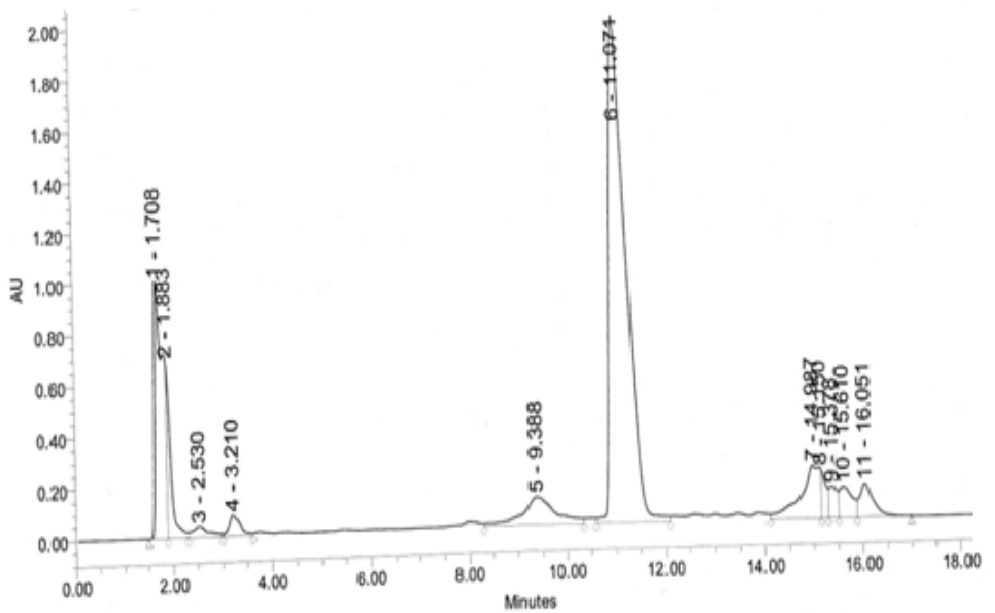

Figure 5 Chromatogram of amino acid composition present in partially purified protein metabolite of Pleurotus strain (Plof-30) tyrosinase analyzed by HPLC.

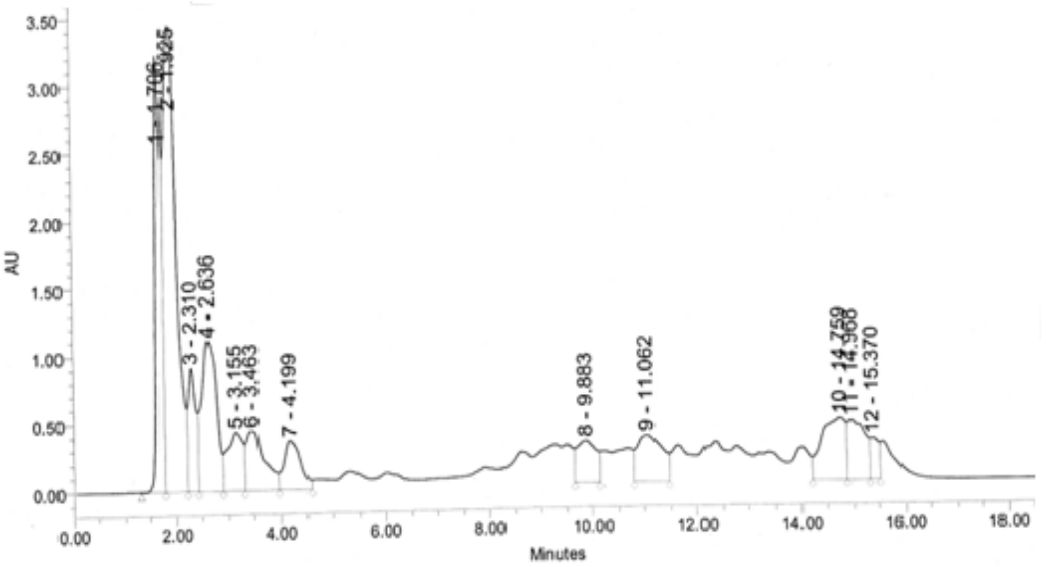

Figure 6 Chromatogram of amino acid composition present in partially purified protein metabolite of Pleurotus strain (Plof-W) analyzed by HPLC.

Journal of Experimental Biology and Agricultural Sciences http://www.jebas.org 


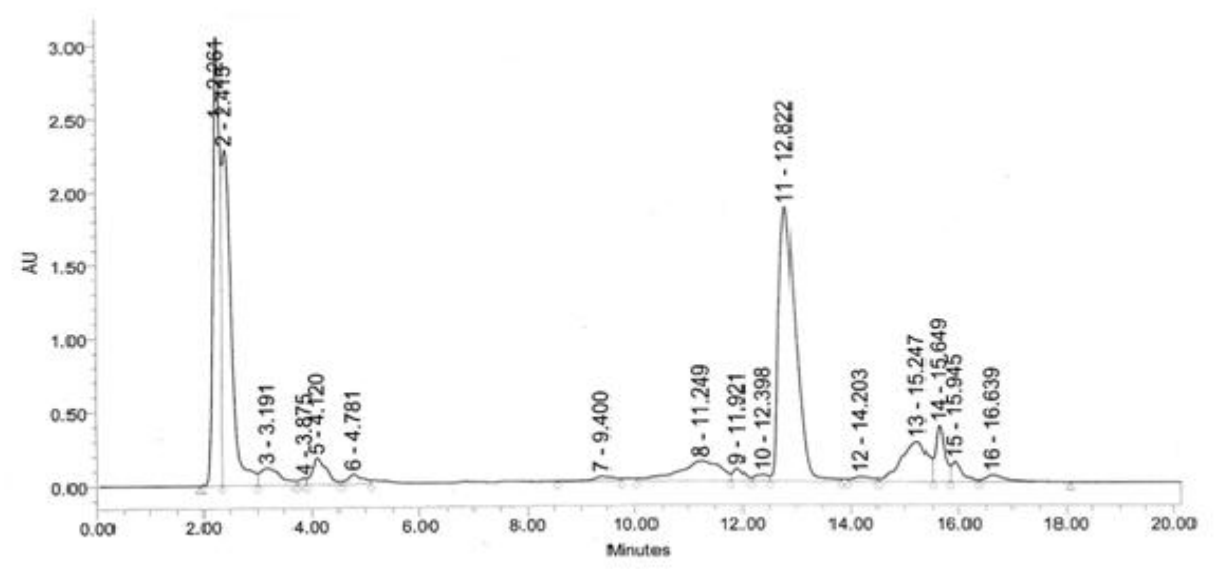

Figure 7 Chromatogram of amino acid composition present in partially purified protein metabolite of Pleurotus strain (Pleu-90) analyzed by HPLC

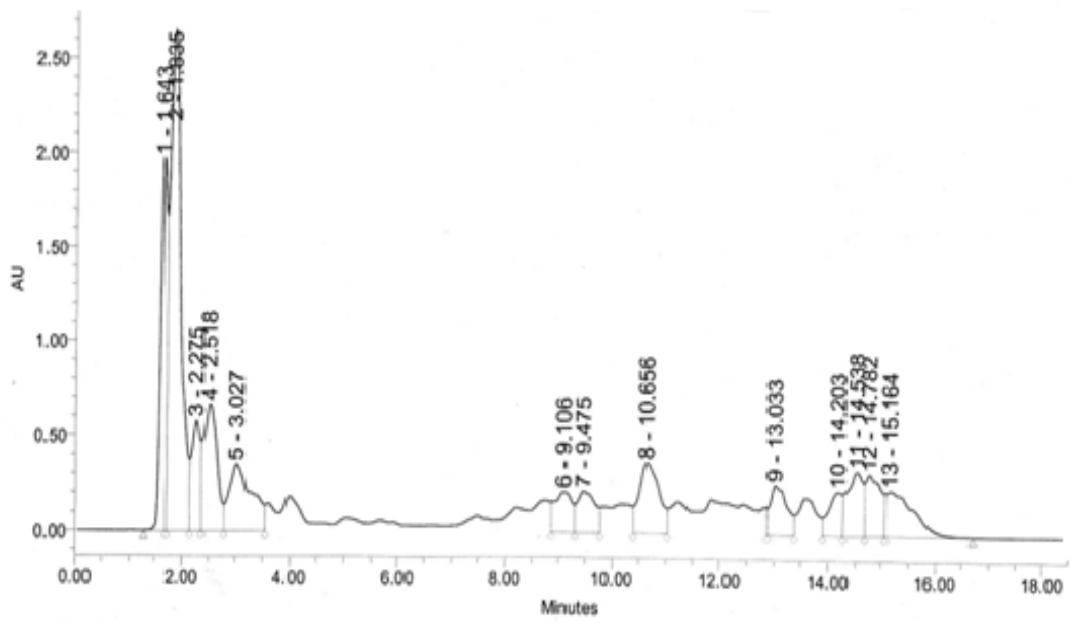

Figure 8 Chromatogram of amino acid composition present in partially purified protein metabolite of Pleurotus strain (Pleu-W) analyzed by HPLC

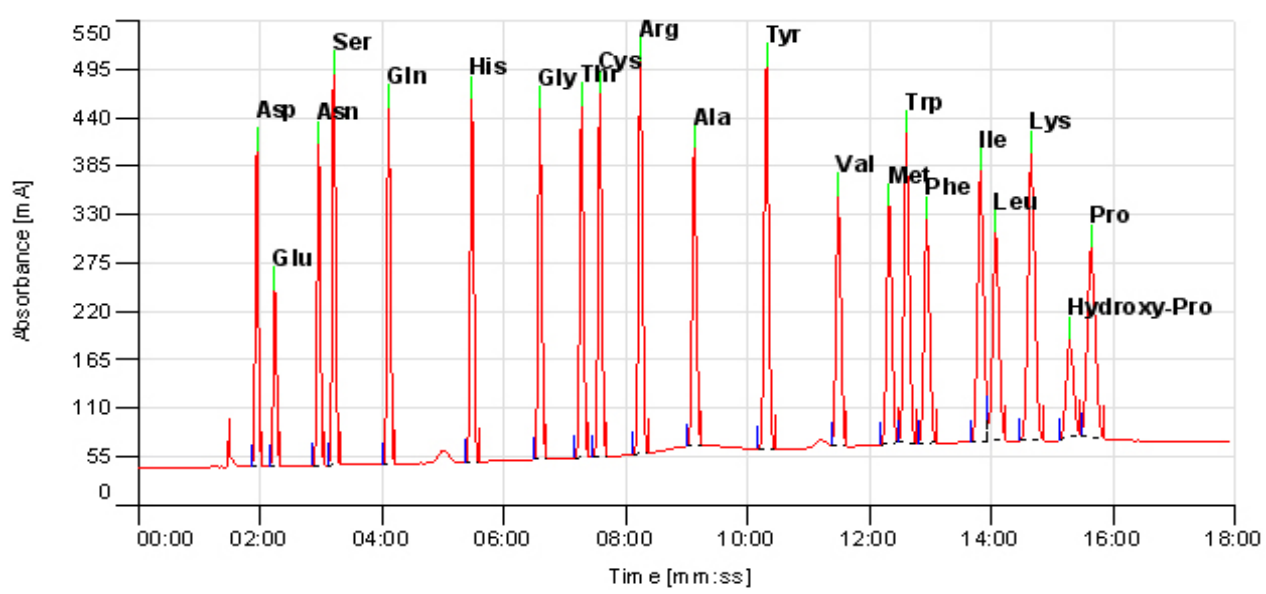

Figure 9 Amino acids standard chromatogram using RP-HPLC

Journal of Experimental Biology and Agricultural Sciences http://www.jebas.org 
Table 1 Quantitative analysis of individual amino acid present in crude protein metabolite of Pleurotus strain (Plof-30).

\begin{tabular}{|c|c|c|}
\hline Peak numbers & Amino acid & $\begin{array}{l}\text { Quantity of Amino } \\
\text { acids ( } \mu \mathrm{mol} / \mathrm{mL})\end{array}$ \\
\hline 1 & Aspartic acid & 196.84 \\
\hline 2 & Glutamic acid & 327.46 \\
\hline 3 & Asparagine & 45.76 \\
\hline 4 & Serine & 47.05 \\
\hline 5 & Glycine & 52.89 \\
\hline 6 & Histidine & 148.12 \\
\hline 7 & Glutamine & 21.19 \\
\hline 8 & Threonine & 18.93 \\
\hline 9 & Alanine & 803.34 \\
\hline 10 & Proline & 35.40 \\
\hline 11 & Tyrosine & 22.45 \\
\hline 12 & Valine & 0.34 \\
\hline 13 & Methionine & 42.12 \\
\hline 14 & Cysteine & 51.13 \\
\hline 15 & Isoleucine & 130.48 \\
\hline 16 & Leucine & 40.97 \\
\hline 17 & Hydroxy-Proline & 4.45 \\
\hline
\end{tabular}

Table 3 Quantitative analysis of individual amino acid present in crude protein metabolite of Pleurotus strain (Pleu-90).

\begin{tabular}{|c|c|c|}
\hline Peak numbers & Amino acid & $\begin{array}{l}\text { Quantity of Amino } \\
\text { acids }(\mu \mathrm{mol} / \mathrm{mL})\end{array}$ \\
\hline 1 & Aspartic acid & 174.19 \\
\hline 2 & Glutamic acid & 268.28 \\
\hline 3 & Serine & 69.26 \\
\hline 4 & Glycine & 44.55 \\
\hline 5 & Threonine & 93.07 \\
\hline 6 & Arginine & 41.05 \\
\hline 7 & Alanine & 47.55 \\
\hline 8 & Tyrosine & 786.94 \\
\hline 9 & Valine & 36.01 \\
\hline 10 & Phenylalanine & 109.91 \\
\hline 11 & Tryptophan & 30.51 \\
\hline 12 & Methionine & 39.69 \\
\hline 13 & Isoleucine & 37.04 \\
\hline 14 & Leucine & 156.44 \\
\hline 15 & Lysine & 88.88 \\
\hline 16 & Proline & 128.81 \\
\hline 17 & Hydroxy-proline & 91.69 \\
\hline
\end{tabular}

Journal of Experimental Biology and Agricultural Sciences http://www.jebas.org
Table 2 Quantitative analysis of individual amino acid present in crude protein metabolite of Pleurotus strain (Plof-W).

\begin{tabular}{|c|c|c|}
\hline Peak numbers & Amino acid & $\begin{array}{l}\text { Quantity of Amino } \\
\text { acids ( } \mu \mathrm{mol} / \mathrm{mL})\end{array}$ \\
\hline 1 & Aspartic acid & 110.96 \\
\hline 2 & Glutamic acid & 434.31 \\
\hline 3 & Asparagine & 148.25 \\
\hline 4 & Serine & 72.20 \\
\hline 5 & Glutamine & 106.09 \\
\hline 6 & Histidine & 119.90 \\
\hline 7 & Alanine & 97.04 \\
\hline 8 & Tyrosine & 280.10 \\
\hline 9 & Valine & 56.22 \\
\hline 10 & Methionine & 190.52 \\
\hline 11 & Tryptophan & 61.73 \\
\hline 12 & Leucine & 70.88 \\
\hline 13 & Cysteine & 216.71 \\
\hline 14 & Isoleucine & 78.08 \\
\hline 15 & Hydroxy-proline & 5.14 \\
\hline 16 & Leucine & 56.19 \\
\hline
\end{tabular}

Table 4 Quantitative analysis of individual amino acid present in crude protein metabolite of Pleurotus strain (Pleu-W).

\begin{tabular}{|c|c|c|}
\hline Peak numbers & Amino acid & $\begin{array}{l}\text { Quantity of Amino } \\
\text { acids ( } \mu \mathrm{mol} / \mathrm{mL})\end{array}$ \\
\hline 1 & Aspartic acid & 240.81 \\
\hline 2 & Glutamic acid & 395.77 \\
\hline 3 & Asparagine & 103.02 \\
\hline 4 & Serine & 60.64 \\
\hline 5 & Cysteine & 95.12 \\
\hline 6 & Arginine & 57.96 \\
\hline 7 & Alanine & 47.54 \\
\hline 8 & Tyrosine & 388.60 \\
\hline 9 & Valine & 34.67 \\
\hline 10 & Methionine & 25.69 \\
\hline 11 & Tryptophan & 47.50 \\
\hline 12 & Phenylalanine & 193.43 \\
\hline 13 & Isoleucine & 41.64 \\
\hline 14 & Leucine & 50.21 \\
\hline 15 & Lysine & 136.96 \\
\hline 16 & Hydroxy-proline & 78.88 \\
\hline 17 & Proline & 129.67 \\
\hline
\end{tabular}


Table 5 Quantitative analysis of individual amino acid present in partially purified protein metabolite of Pleurotus strain (Plof-30).

\begin{tabular}{|c|c|c|}
\hline Peak numbers & Amino acid & $\begin{array}{l}\text { Quantity of Amino } \\
\text { acids }(\mu \mathrm{mol} / \mathrm{mL})\end{array}$ \\
\hline 1 & Aspartic acid & 640.24 \\
\hline 2 & Glutamic acid & 665.72 \\
\hline 3 & Serine & 72.15 \\
\hline 4 & Glycine & 9.27 \\
\hline 5 & Histidine & 77.95 \\
\hline 6 & Arginine & 29.88 \\
\hline 7 & Threonine & 21.58 \\
\hline 8 & Alanine & 6.47 \\
\hline 9 & Proline & 26.50 \\
\hline 10 & Tyrosine & 17.61 \\
\hline 11 & Valine & 894.61 \\
\hline 12 & Methionine & 18.81 \\
\hline 13 & Cysteine & 202.68 \\
\hline 14 & Isoleucine & 104.95 \\
\hline 15 & Leucine & 44.88 \\
\hline 16 & Phenylalanine & 29.40 \\
\hline
\end{tabular}

Table 7 Quantitative analysis of individual amino acid present in partially purified protein metabolite of Pleurotus strain (Pleu-90)

\begin{tabular}{|ccc|}
\hline Peak numbers & Amino acid & $\begin{array}{c}\text { Quantity of Amino } \\
\text { acids }(\mu \mathrm{mol} / \mathrm{mL})\end{array}$ \\
\hline 1 & Aspartic acid & 261.13 \\
\hline 2 & Glutamic acid & 88.33 \\
\hline 3 & Serine & 22.53 \\
\hline 4 & Glycine & 30.37 \\
\hline 5 & Threonine & 119.78 \\
\hline 6 & Alanine & 1084.61 \\
\hline 7 & Proline & 127.83 \\
\hline 8 & Tyrosine & 29.34 \\
\hline 9 & Valine & 30.67 \\
\hline 10 & Methionine & 49.71 \\
\hline 11 & Cysteine & 55.75 \\
\hline
\end{tabular}

\subsubsection{Essential and non-essential amino acids percentage} composition

The results presented in Figures $10-13$ showed the percentages of essential and non-essential amino acids found in crude and partially purified protein metabolite samples for the four Pleurotus strains. The results indicated that the percentage
Table 6 Quantitative analysis of individual amino acid present in partially purified protein metabolite of Pleurotus strain (Plof-W)

\begin{tabular}{|ccc|}
\hline Peak numbers & Amino acid & $\begin{array}{c}\text { Quantity of Amino acids } \\
(\mu \mathrm{mol} / \mathrm{mL})\end{array}$ \\
\hline 1 & Aspartic acid & 298.20 \\
\hline 2 & Glutamic acid & 914.26 \\
\hline 3 & Serine & 143.56 \\
\hline 4 & Glycine & 254.57 \\
\hline 5 & Histidine & 230.32 \\
\hline 6 & Arginine & 104.20 \\
\hline 7 & Threonine & 115.01 \\
\hline 8 & Alanine & 208.60 \\
\hline 9 & Proline & 126.10 \\
\hline 10 & Tyrosine & 89.59 \\
\hline 11 & Valine & 151.87 \\
\hline 12 & Methionine & 145.90 \\
\hline 13 & Cysteine & 193.55 \\
\hline
\end{tabular}

Table 8 Quantitative analysis of individual amino acid present in partially purified protein metabolite of Pleurotus strain (Pleu-W).

\begin{tabular}{|ccc|}
\hline Peak numbers & Amino acid & $\begin{array}{c}\text { Quantity of Amino acids } \\
(\mu \mathrm{mol} / \mathrm{mL})\end{array}$ \\
\hline 1 & Aspartic acid & 513.20 \\
\hline 2 & Glutamic acid & 1343.26 \\
\hline 3 & Asparagine & 215.01 \\
\hline 4 & Serine & 466.23 \\
\hline 5 & Glycine & 208.16 \\
\hline 6 & Histidine & 241.79 \\
\hline 7 & Arginine & 181.32 \\
\hline 8 & Threonine & 184.53 \\
\hline 9 & Alanine & 225.11 \\
\hline 10 & Proline & 334.29 \\
\hline 11 & Tyrosine & 22.45 \\
\hline 12 & Valine & 0.34 \\
\hline
\end{tabular}

distribution of non-essential amino acids was $27.23 \%$ for PlofW and Plof-30, while it was $25.73 \%$ for Pleu-W and $19.81 \%$ for Pleu-90 in the crude protein sample analyzed. For the essential amino acids composition in the crude metabolite analyzed, Pleu-90 had the highest percentage of $31.82 \%$, followed by Pleu-W with $27.27 \%$. Furthermore, the analysis of partially purified protein metabolite from the fungal strains indicated 
that (Plof-W) had the highest percentage of non-essential amino acids $27.78 \%$ and for the essential amino acids; among the tested compositions, Plof-30 had the highest percentage composition with $42.86 \%$.

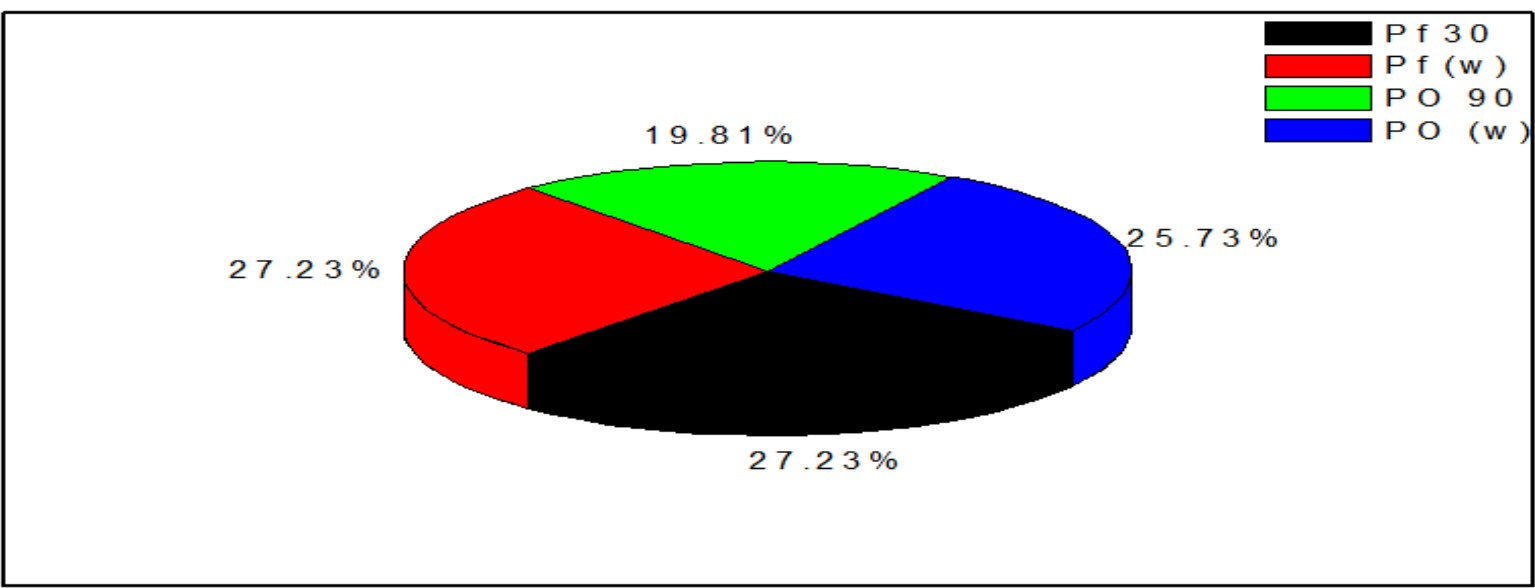

Figure 10 Percentages of non-essential amino acids in crude protein metabolite of edible Pleurotus strains

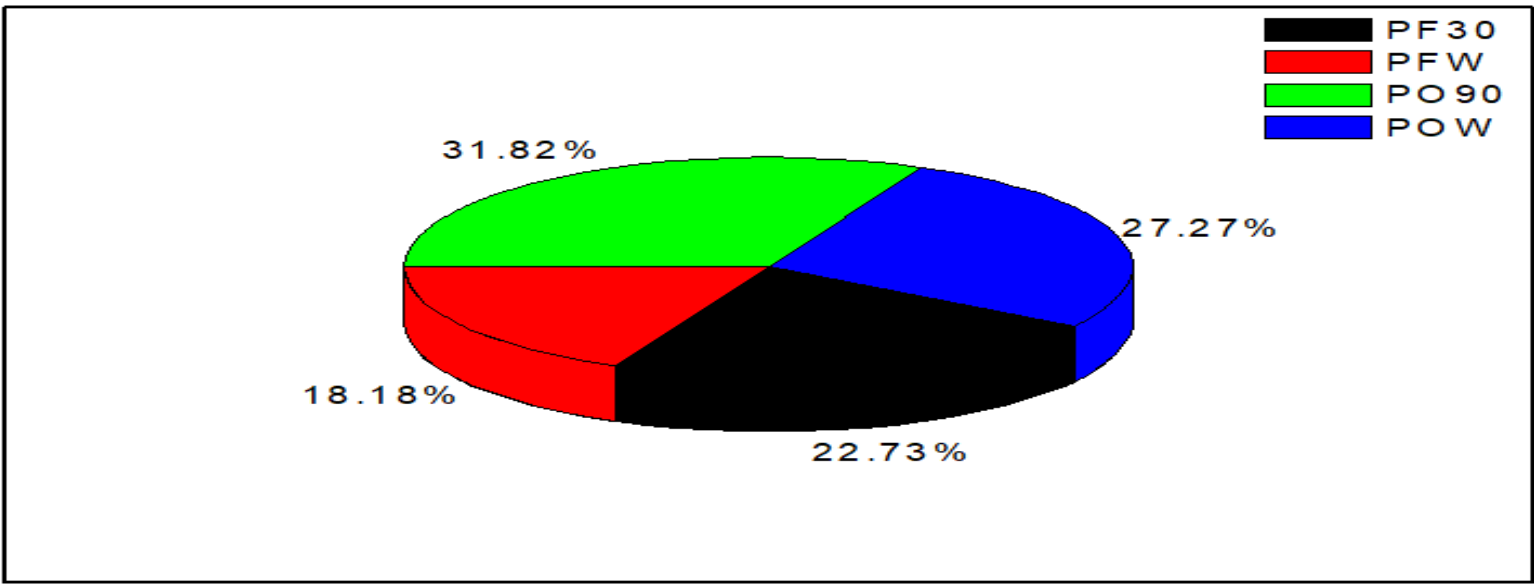

Figure 11 Percentages of essential amino acids in crude protein metabolite of edible Pleurotus strains.

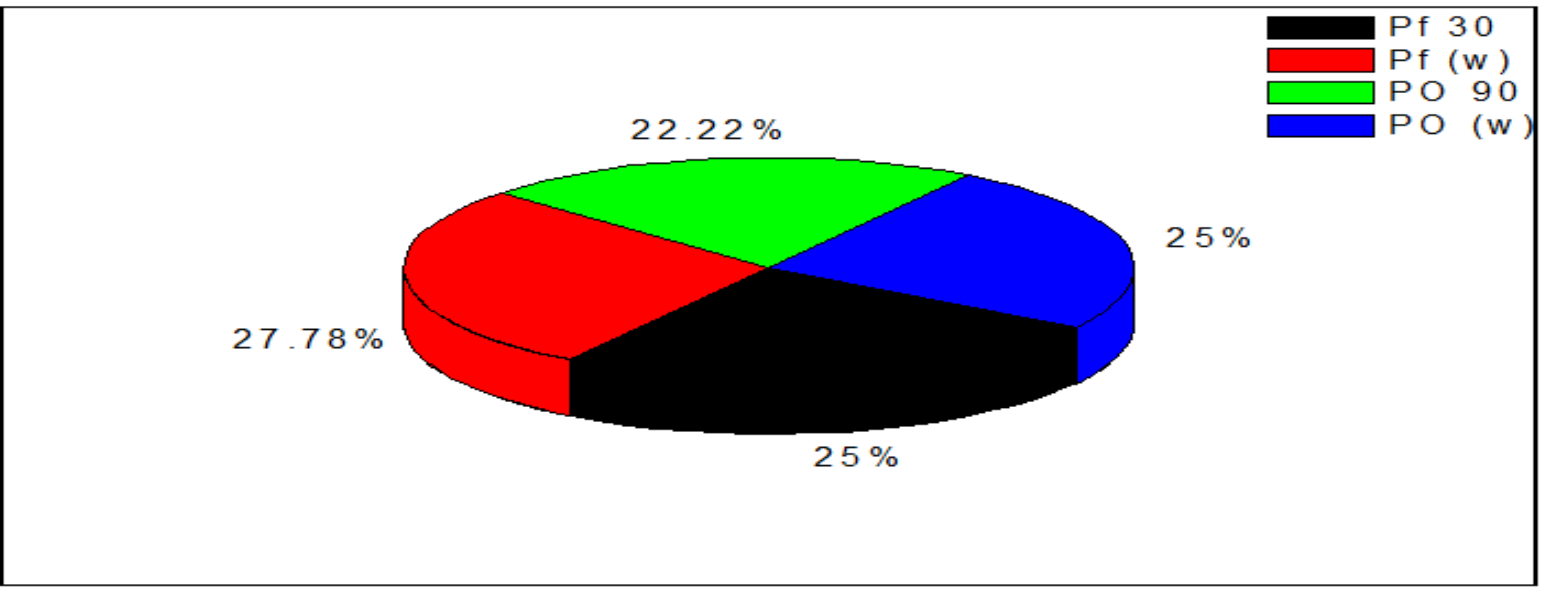

Figure 12 Percentages of non-essential amino acids in partially purified protein metabolite of edible Pleurotus strains

Journal of Experimental Biology and Agricultural Sciences http://www.jebas.org 


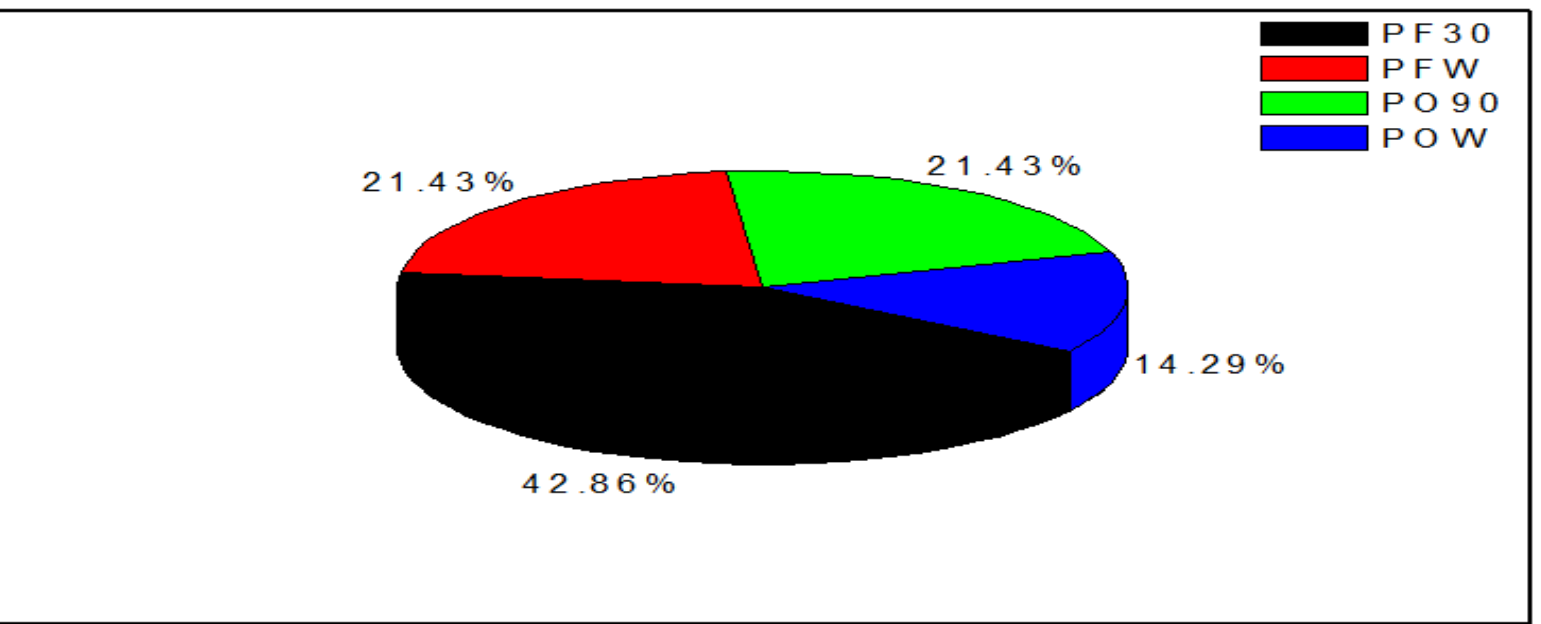

Figure 13 Percentages of essential amino acids in partially purified protein metabolite of edible Pleurotus strains.

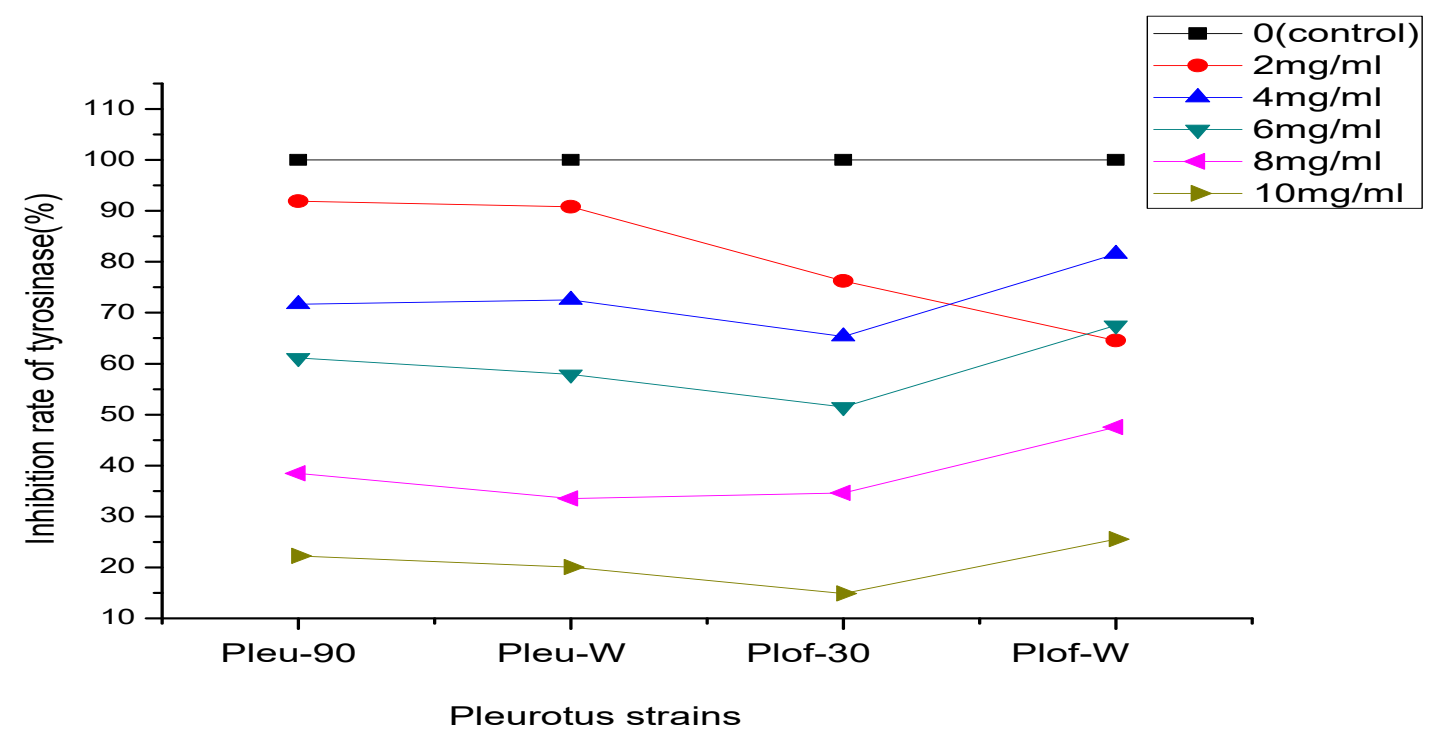

Figure 14 Inhibitory effects of different concentrations of DL-Aspartic acid on tyrosinase activity of four Pleurotus strains.

\subsection{Anti-tyrosinase inhibitory studies}

The results obtained with the effect of various concentrations of DL-Aspartic acid on the activity of tyrosinase are presented in figure 14. Tyrosinase activity was markedly inhibited by the concentration of $10 \mathrm{mg} / \mathrm{ml}$ of DL-Aspartic acid in all four fungal strains. DL-Aspartic acid at $10 \mathrm{mg} / \mathrm{ml}$ resulted in the various inhibition rate from $14.86 \%$ (Plof-W), to 20.06 (Pleu-90), 22.27\% (Pleu-W), and lastly $25.54 \%$ for Plof-30.

In addition, the tyrosinase inhibitory effects of Ascorbic acid and EDTA on the activity of fungal tyrosinase are also shown in Figures 15 and 16. These results confirmed that all four fungal strains were inhibited at $10 \mathrm{mg} / \mathrm{ml}$ concentration considerably. The ascorbic acid inhibitory results indicated that the highest inactivation percentage of $30.36 \%$ was attained with Pleurotus strain Pleu-90, while Pleurotus strain Plof-W had the highest inactivation percentage of $50.91 \%$ when EDTA was used in combination.

Also, the inhibitory effect of different concentrations of Gallic acid on fungal tyrosinase activity is shown in Figure 17. The result showed high inhibitory activity when a $10 \mathrm{mg} / \mathrm{ml}$ concentration of gallic acid was also estimated and reported different inhibition rates for different strains and this was reported 24.55\%, 32.7\%, $44.78 \%$, and $51.42 \%$ for Plof-W, Plof-30, Pleu-W, and Pleu-90 respectively. 


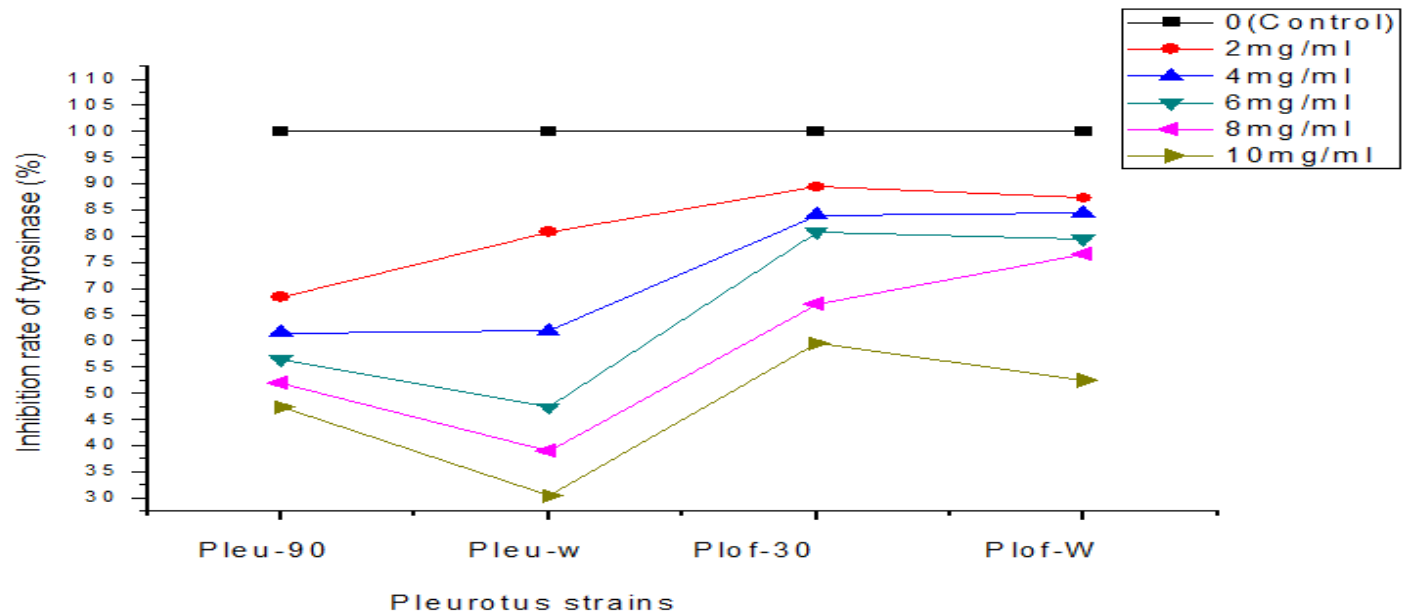

Figure 15 Inhibitory effects of different concentrations of Ascorbic acid on tyrosinase activity of four Pleurotus strains.

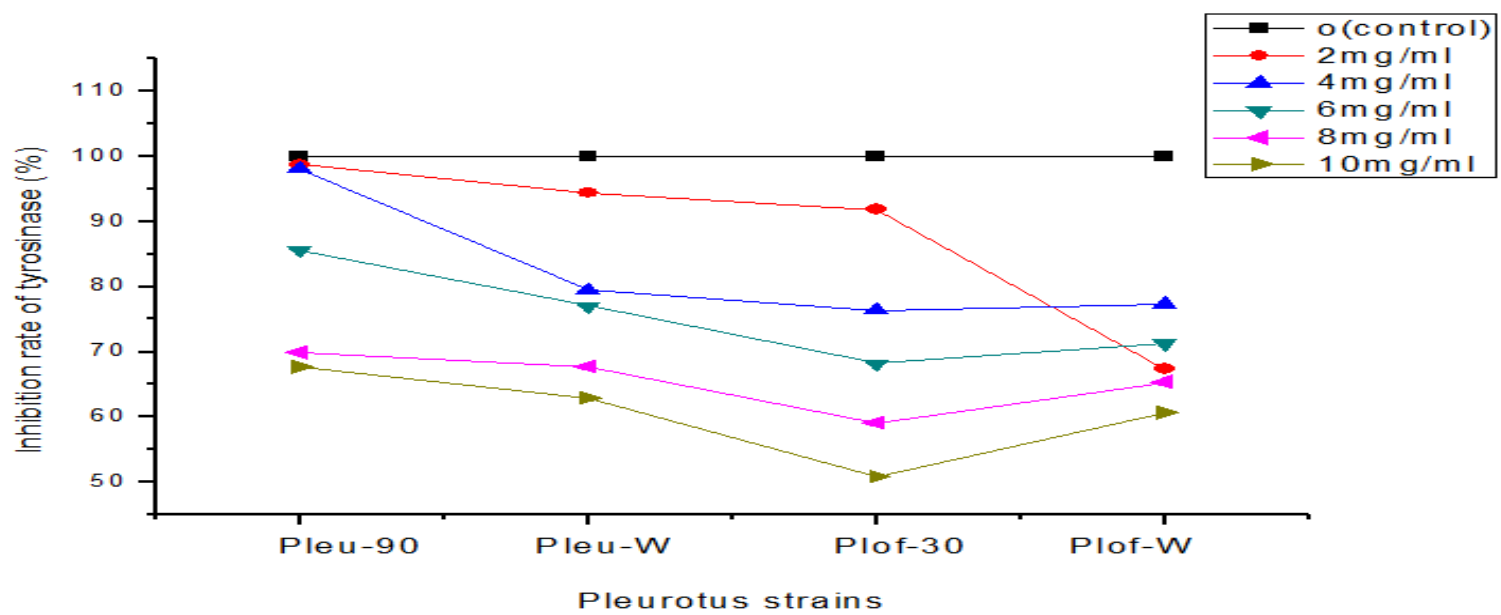

Figure 16 Inhibitory effect of different concentrations of EDTA on tyrosinase activity of four Pleurotus strains.

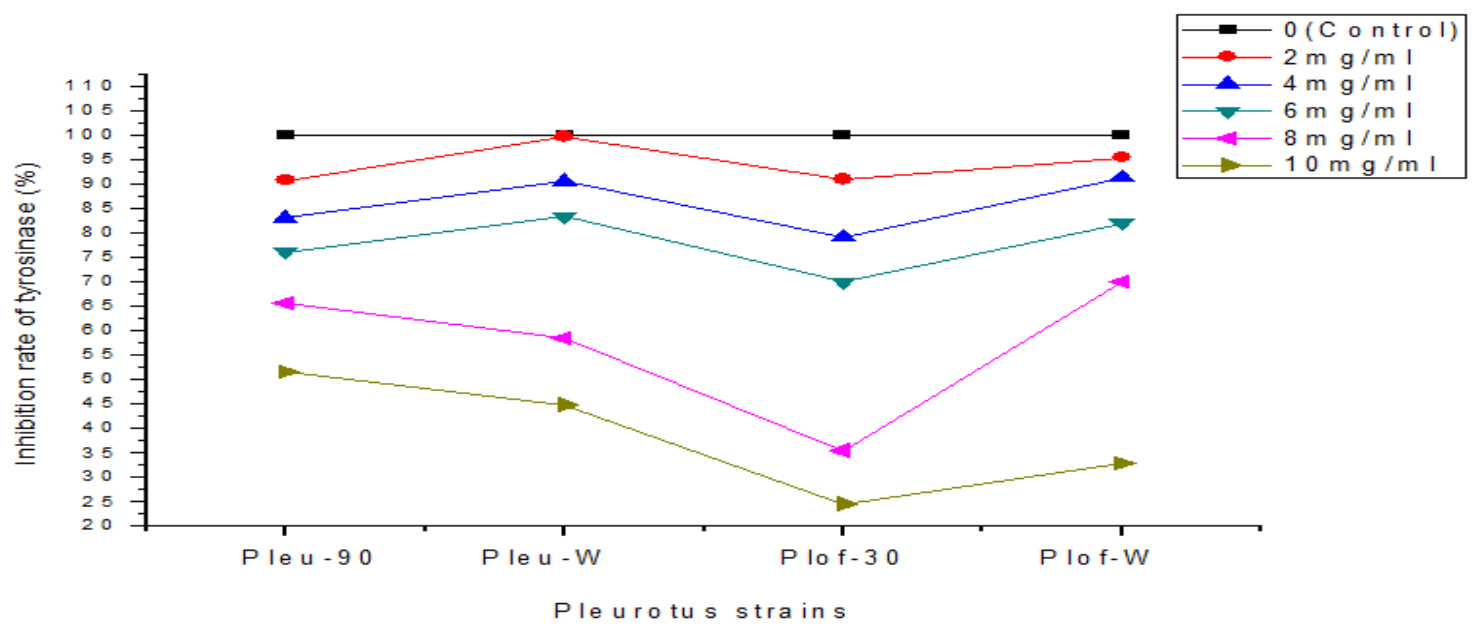

Figure 17 Inhibitory effect of different concentrations of Gallic acid on tyrosinase activity of four Pleurotus strains.

Journal of Experimental Biology and Agricultural Sciences http://www.jebas.org 


\section{Discussion}

Mushrooms are appreciated globally because they are the source of immense benefits to humans and the environment. They are nutritionally and functionally beneficial, and useful in tackling a lot of waste problems in society. Mushrooms are a goldmine of potential scientific and commercial bioactive metabolites like important enzymes, enzyme inhibitors, and nutraceuticals that can be biotechnological applied for useful purposes. This study focused on determining the amino acid composition and assessing the anti-tyrosinase inhibitory activities of metabolites from four selected oyster mushrooms that were cultivated under liquid fermentation to authenticate their nutritional and therapeutic potency.

Results obtained from the analysis of crude and partially purified protein metabolites from the strains of the Pleurotus species used in the investigation indicated that it is composed of 17 different amino acids. The amino acids not detected in this study could be explained as enough quantities of the amino acids could not be fluorescence because of variations in experimental parameters.

Taken together, the profiles of the amino acid of the four oyster mushroom strains are comparable because they all are from the Pleurotaceae family. Generally, the crude tyrosinase had a higher quantity of amino acids than the partially purified type. Also, the result showed varying percentages of essential and non-essential amino acids are found in crude and partially purified protein metabolite samples for all the mushroom strains. Concerning abundance, glutamic acid, alanine, and valine are the topmost amino acids found in mushroom strains.

These findings are nearly in tandem with results obtained in the work done by various researchers (Manzi et al., 1999; Mattila et al., 2002; Akindahunsi \& Oyetayo, 2006; Pornariya \& Kanok-Orn, 2009; Kayode et al., 2015; Maninen et al., 2018; Jaures et al., 2019; Yin et al., 2019) on different mushroom species. They reported that an appreciable amount of total amino acids was present in different mushrooms that included Pleurotus species and glutamic acid, aspartic acid and arginine were more in terms of their abundance.

Changes observed in the quantity and composition of amino acids found in this similar (Pleurotus strains) could be due to diverse production/ cultivation parameters and also due to genetic shift/variation as explained in earlier studies (Chiu et al. 1998; Mendez et al. 2005; Zhang et al. 2013).

The findings indicated that tryptophan was minute relative to other amino acids abundance in the four Pleurotus strains which are in agreement with the reports of Manzi et al. (1999) and Mdachi et al.
(2004). Of importance, mushroom metabolites are known vital resources that possess nutritional and therapeutic benefits, which have a complete amino acids production profile (essential and nonessential)

Some of these amino acids present in mushrooms like arginine are effective as functional supplements in most cancer patients by boosting their immunity, delaying the rapid and uncontrollable growth of cancerous cells, enhancing their life expectancy among other benefits (Novaes et al., 2011). Furthermore, tyrosinase and its inhibitors have received increasing attention lately as biotechnologically vital biometabolite worthy of further investigations. In the current study also moderate to higher antityrosinase inhibitory activity was reported and this is concentration dependent. The results reported by Fattahifar et al. (2018), Li et al. (2019), and Selinheimo et al. (2006) in their different investigations are in agreement with the results of the present findings. Also, the studies on different tyrosinase inhibitors from diverse synthetic and natural sources were comprehensively reported an appreciable tyrosinase inhibitory activity and these results are correlated with the findings of the current study (Wang et al. 2015; Mukherjee et al., 2018; Zolghadri et al., 2019).

The mechanisms attributable/behind the inhibitory effect were reported to be substrate permission of access to active site through structural modifications; also, the inhibitors copper chelating capability (Baek et al., 2008; Hu et al. 2016), which ultimately reduces the enzymatic activity. More so, the antioxidant potency of these inhibitors is also a possible mechanism for anti-tyrosinase actions (Momtaz et al. 2008).

However, further research studies are required to be carried out to elucidate the mechanisms behind the inhibitory activities of these oyster mushroom metabolite extracts. The catalytic studies and kinetics of the inhibitory actions are also needed to be determined in a future study.

\section{Conclusion}

In conclusion, our results from this investigation affirmed that metabolites from edible Pleurotus strains are a repository of bioactive metabolites that can be explored for their biotechnological potentials in terms of their nutritious functional food status and therapeutic application potentials for the benefits of man and the society at large.

\section{Acknowledgments}

The authors did not receive any financial funding from an external body but are grateful to the authorities of LAUTECH and CSIRNEIST for providing facilities. 


\section{References}

Akindahunsi AA, Oyetayo FL (2006) Nutrient and antinutrient distribution of edible mushroom, Pleurotus tuber-regium (fries) singer. LWT Food Science and Technology 39:548-553.

Arung ET, Shimizu K, Kondo R (2006) Inhibitory effect of artocarpanone from Artocarpus heterophyllus on melanin biosynthesis. Biological and Pharmaceutical Bulletin 29:1966 1969.

Bach F, Helm CV, Bellettini MB, Maciel GM, Haminiuk CWI (2017) Edible mushrooms: A potential source of essential amino acids, glucans and minerals. International Journal of Food Science \& Technology 52(11): 2382-2392. https://doi.org/10.1111/ ijfs. 13522 .

Baek HS, Rho HS, Yoo JW, Ahn SM, Lee JY, Lee J, Kim MK, Kim DH, Chang I S (2008) The inhibitory effect of new hydroxamic acid derivatives on melanogenesis. Bulletin of the Korean Chemical Society 29: 43-46.

Carrasco-González JA, Serna-Saldívar SO, Gutiérrez-Uribe JA (2017) Nutritional composition and nutraceutical properties of the Pleurotus fruiting bodies: potential use as food ingredient. Journal of Food Composition and Analysis 58: 69-81.

Chandra P, Sharma RK, Arora D S (2020) Antioxidant compounds from microbial sources: A review. Food Research International 129: 108849.DOI: 10.1016/j.foodres.2019.108849.

Chiu SW, Chan YH, Law SC, Cheung KT, Moore D (1998) Cadmium and manganese in contrast to calcium reduce yield and nutritional values of the edible mushroom Pleurotus pulmonarious. Mycological Research102: 449-457.

Corrêa RCG, Brugnari T, Bracht A, Peralta RM, Ferreira IC (2016) Biotechnological, nutritional and therapeutic uses of Pleurotus spp (Oyster mushroom) related with its chemical composition: a review on the past decade findings. Trends in Food Science and Technology 50: 103-117.

Deepalakshmi K, Mirunalini S (2014) Pleurotus ostreatus: an oyster mushroom with nutritional and medicinal properties. Journal Biochemical Technology 5:718-726.

Dembitsky VM, Kilimnik A (2016) Anti-melanoma agents derived from fungal species. Mathews Journal of Pharmaceutical Science $1: 1-16$.

Dicks L, Ellinger S (2020) Effect of the intake of oyster mushrooms (Pleurotus ostreatus) on cardiometabolic parametersA systematic review of clinical trials. Nutrients 12: 1134. doi: 10.3390/nu12041134.
Fattahifar E, Barzegar M, Ahmadi Gavlighi H, Sahari MA (2018) Evaluation of the inhibitory effect of pistachio (Pistacia vera L.) green hull aqueous extract on mushroom tyrosinase activity and its application as a button mushroom postharvest anti-browning agent. Postharvest Biology and Technology 145: 157-165.

Haghbeen K, Tan EW (2003) Direct spectrophotometric assay of monooxygenase and oxidase activities of mushroom tyrosinase in the presence of synthetic and natural substrates. Analytical Biochemistry 312: 23-32.

Halaouli S, Asther Mi, Kruus K, Guo L, Hamdi M, Sigoillot JC, Asther M, Lomascolo A (2005) Characterization of a new tyrosinase from Pycnoporus species with high potential for food technological applications. Journal of Applied Microbiology 98: 332-343.

Halaouli S, Asther M, Sigoillot JC, Hamdi M, Lomascolo A (2006) Fungal tyrosinases: new prospects in molecular characteristics, bioengineering and biotechnological applications. Journal of Applied Microbiology 100(2): 219-232.

Hu YH, Chen QX, Cui Y, Gao HJ, Xu L, Yu X Y (2016) 4Hydroxy cinnamic acid as mushroom preservation: Anti-tyrosinase activity kinetics and application. International Journal of Biological Macromolecule 86: 489-495.

Ianni F, Blasi F, Angelini P, Di Simone SC, Angeles Flores G, Cossignani L, Venanzoni R (2021) Extraction Optimization by Experimental Design of Bioactives from Pleurotus ostreatus and Evaluation of Antioxidant and Antimicrobial Activities. Processes 9: 743. DOI:10.3390/pr9050743.

Jaures G, Kouassi A, Konan H, Parfait J (2019) Proximate composition and nutritional value of three edible mushrooms ectomycorrhizal (Russula mustelina, Russula Delica and Russula lepida) from Côte d'Ivoire according to the maturity stages. World Journal of Advanced Research and Reviews 2:021-030. DOI:10.30574/wjarr.2019.2.3.0040.

Kalac P (2013) A review of chemical composition and nutritional value of wild-growing and cultivated mushrooms: chemical composition of edible mushrooms. Journal of Science of Food and Agriculture 93: 209-218.

Kayode R, Olakulehin TF, Adedeji BS, Ahmed O, Aliyu T, Badmos AHA (2015) Evaluation of Amino Acid and Fatty Acid Profiles of Commercially Cultivated Oyster Mushroom (Pleurotussajor caju) Grown on Gmelina Wood Waste. Nigerian Food Journal 503. http://dx.doi.org/10.1016/j.nifoj.2015.04.001.

Kubo I, Chen QX, Nihei K (2003) Molecular design of antibrowning agents: antioxidative tyrosinase inhibitors. Food Chemistry 81: 241-247. 
Li B, Ding Y, Tang X, Wang G, Wu S, Li X (2019) Effect of Larginine on maintaining storage quality of the white button mushroom (Agaricus bisporus). Food Bioprocess Technology 12(4): $563-574$

Manninen H, Rotola-Pukkila M, Aisala H, Hopia A, Laaksonen T (2018) Free amino acids and 5-nucleotides in Finnish fores mushrooms. Food Chemistry 247:23-28.

Manzi P, Gambelli L, Marconi S, Vivanti V, Pizzoferrato L. (1999) Nutrients in edible mushrooms: an interspecies comparative study. Food Chemistry 65: 477-482.

Mattila P, Salo-Vaananen P, Konko K, Aro H, Jalava T (2002) Basic composition and amino acid contents of mushrooms cultivated in Finland. Journal of Agriculture and Food Chemistry 50: 6419-6422.

Mdachi SJM, Nkuny MHH, Nyigo VA, Urasa IT (2004) Amino acid composition of some Tanzanian wild mushrooms. Food Chemistry 86: 179-182.

Mendez LA, Castro CAS, Casso RB, Leal CMC (2005) Effect of substrate and harvest on the amino acid profile of oyster mushroom (Pleurotus ostreatus). Journal of Food Composition and Analysis 18: 447-450.

Michael HW, Bultosa G, Pant LM (2011) Nutritional contents of three edible oyster mushrooms grown on two substrates at Haramaya, Ethiopia, and sensory properties of boiled mushroom and mushroom sauce: nutrient of edible oyster mushrooms Internal Journal of Food Science and Technology 46:732-738.

Momtaz S, Mapunya BM, Houghton PJ, Edgerly C, Hussein A, Naidoo S, Lall N (2008) Tyrosinase inhibition by extracts and constituents of Sideroxylon inerme L. stem bark, used in South Africa for skin lightening. Journal of Ethnopharmacology 119: $507-512$

Mukherjee PK, Biswas R, Sharma A, Banerjee S, Biswas S, Katiyar CK (2018) Validation of medicinal herbs for antityrosinase potential. Journal of Herbal Medicine 14: 1-16.

Novaes MR, Valadares F, Reis MC, Gonçalves DR, Menezes MC (2011) The effects of dietary supplementation with Agaricales mushrooms and other medicinal fungi on breast cancer: Evidence Based Medicine 66: 2133-2139.
Öztürk M, Tel-Cayan G, Muhammad A, Terzioglu P, Duru M E (2015) Mushrooms: A source of exciting bioactive compounds. In: Atta-ur-Rahman (Ed.), Studies in natural product chemistry, Amsterdam, Netherlands: Elsevier, Pp. 363-456.

Pornariya C, Kanok-Orn I (2009) Amino acids and antioxidant properties of the oyster mushrooms, Pleurotus ostreatus and Pleurotus sajor-caju. Science Asia 35: 326-331.

Sahu RK, Roy A, Dwivedi J, Jha AK (2014) Promotion and computation of inhibitory effect on tyrosinase activity of herbal cream by incorporating indigenous medicinal plants. Pakistan Journal of Biological Science 17: 146-150.

Sekan AS, Myronycheva OS, Karlsson O, Gryganskyi AP, Blume Y (2019) Green potential of Pleurotus spp in biotechnology. PeerJ 7: e6664 DOI 10.7717/peerj.6664.

Selinheimo E, Saloheimo M, Ahola E, Westerholm-Parvinen A, Kalkkinen N, Buchert J, Kruus K (2006) Production and characterization of a secreted $\mathrm{C}$-terminally processed tyrosinase from the filamentous fungus Trichoderma reesei. FEBS Journal 273: 4322-4335

Te-Cheng C (2009) An updated review of tyrosinase inhibitors. International Journal of Molecular Sciences 10(6): 2440-2447.

Wang Z, Chen L, Yang H, Wang A (2015) Effect of exogenous glycine betaine on qualities of button mushrooms (Agaricus bisporus) during postharvest storage. European Food Research Technology 240(1): 41-48.

Yin C, Fan X, Fan Z, Shi D, Yao F, Gao H (2019) Comparison of non-volatile and volatile flavor compounds in six Pleurotus mushrooms. Journal of the Science of Food and Agriculture 99: $1691-1699$

Zhang Y, Venkitasamy C, Pan Z, Wang W (2013) Recent developments on umami ingredients of edible mushrooms - a review. Trends in Food Science \& Technology 33:78-92.

Zolghadri S, Bahrami A, Hassan Khan MT, Munoz-Munoz J, Garcia-Molina F, Garcia-Canovas F (2019) A comprehensive review on tyrosinase inhibitors. Journal of Enzyme Inhibition and Medicinal Chemistry 34(1): 279-309. 